\title{
PENERAPAN STRATEGI PREVIEW, QUESTION, READ, REFLECT, RECITE, AND REVIEW UNTUK MENINGKATKAN KEMAMPUAN REPRESENTASI MATEMATIS SISWA KELAS VII SMP NEGERI 1 TANAH JAMBO AYE
}

\author{
Niatul Jannah $^{1)}$, Muliana ${ }^{2)^{*}}$, Marhami ${ }^{3)}$ \\ ${ }^{1.2 .3}$ Program Studi Pendidikan Matematika, Universitas Malikussaleh, Aceh Utara, Aceh, \\ *Korespondensi Penulis. E-mail: muliana.mpd@unimal.ac.id
}

\begin{abstract}
Abstrak
Penelitian ini bertujuan untuk mengetahui apakah terdapat peningkatan kemampuan representasi matematis siswa pada kelas VII SMP Negeri 1 Tanah Jambo Aye dengan penerapan strategi Preview Question, Read, Reflect, Recite and Review. Penelitian ini menggunakan pendekatan kuantitatif dengan jenis penelitian eksperimen tipe Quasi Eksperimental dan desain penelitian Nonequivalent Control Group Design. Populasi dalam penelitian ini adalah seluruh siswa kelas VII SMP Negeri 1 Tanah Jambo Aye tahun ajaran 2020/2021. Penentuan sampel yaitu menggunakan teknik Purposive Sampling, diperoleh dua kelas yaitu kelas VII/6 sebagai kelas eksperimen dan kelas VII/7 sebagai kelas kontrol. Kelas eksperimen dalam perlakuannya menggunakan pembelajaran saintifik dengan strategi PQ4R sedangkan kelas kontrol menggunakan pembelajaran saintifik saja. Pengolahan data dari hasil penelitian yaitu menggunakan statistik deskriptif dan uji-t berbantuan program SPSS versi 17. Hasil penelitian menunjukkan bahwa terdapat perbandingan pada data $N$-Gain yaitu kelas eksperimen yang menggunakan pembelajaran saintifik dengan strategi PQ4R lebih baik dari pada kelas kontrol yang menggunakan pembelajaran saintifik. Berdasarkan uji-t menggunakan Compare Means Independent-Samples T Test diperoleh signifikan 0,000 < taraf signifikan $\alpha=0,05$ berarti tolak $\mathrm{H}_{0}$ sehingga dapat disimpulkan bahwa peningkatan kemampuan representasi matematis siswa yang diterapkan dengan pembelajaran saintifik dengan strategi PQ4R lebih baik dari pada yang diterapkan dengan pembelajaran saintifik pada kelas VII SMP Negeri 1 Tanah Jambo Aye.
\end{abstract}

Kata Kunci: Kemampuan Representasi Matematis, Pembelajaran Saintifik, Strategi PQ4R (Preview Question, Read, Reflect, Recite and Review).

\section{PENDAHULUAN}

Pembelajaran matematika ialah suatu proses kompleks serta melibatkan berbagai aspek dan saling berkaitan. (Mariyam, Nurdin, \& Utami, C, 2019) mengemukakan bahwa penguasaan matematika yang kuat sejak dini diperlukan siswa untuk menguasai dan menciptakan teknologi di masa depan. Tujuan pembelajaran matematika dalam Kurikulum 2013 revisi atau yang kini disebut dengan kurikulum nasional, siswa lebih dituntut untuk aktif, kreatif dan inovatif dalam menyelesaikan masalah yang mereka hadapi disekolah, sehingga siswa dituntut untuk dapat mengembangkan kemampuan matematis yang dimilikinya (Yustika \& Roesdinan, L, 2021). Dengan mengembangkan kemampuan matematis ini siswa dapat lebih memahami konsep yang dipelajari, dapat menerapkannya pada berbagai situasi dalam kehidupan sehari-hari. 


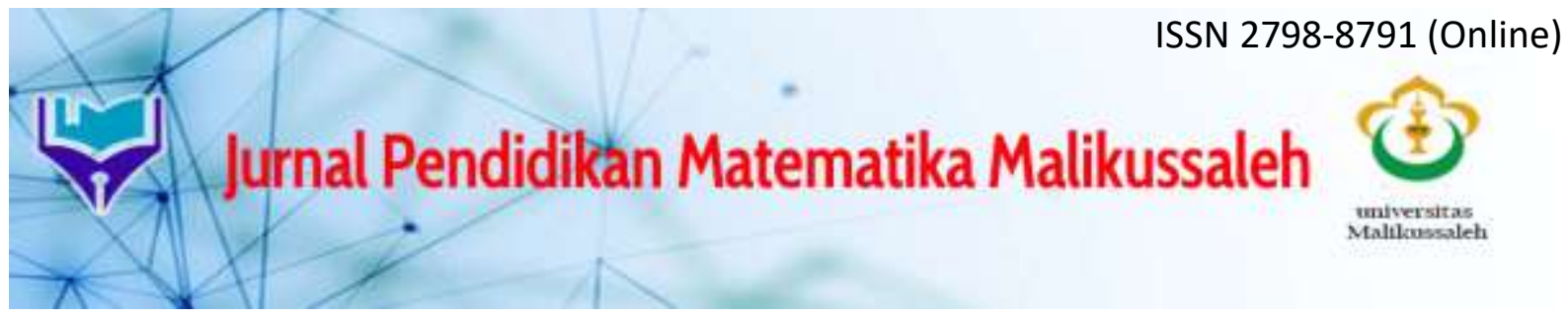

Volume 1, Nomor 2, November 2021

National Council Teacher of Mathematics (NCTM, 2000) menetapkan standar-standar kemampuan matematis yang perlu dimiliki oleh siswa yaitu: (1) pemecahan masalah matematis (mathematical problem solving), (2) komunikasi matematis (mathematical communication), (3) penalaran dan pembuktian matematis (mathematical reasoning and proof), (4) koneksi matematis (mathematical connection), dan (5) representasi matematis (mathematical representation). Dari lima kemampuan tersebut, representasi matematis sangatlah penting untuk dikembangkan karena digunakan sebagai dasar pembelajaran matematika dan mampu mempermudah siswa dalam mempelajari matematika.

Namun kenyataannya, kemampuan representasi matematis siswa masih tergolong rendah. Hal ini sesuai dengan hasil PPL (Praktik Pengalaman Lapangan) selama sebulan dan disertai wawancara bersama salah satu guru matematika Ibu Devi Maulina, S.Pd di SMP Negeri 1 Tanah Jambo Aye pada tanggal 20 Januari 2021, diperoleh bahwa (1) jika dihadapkan dengan soal-soal cerita yang berkaitan dengan kehidupan sehari-hari, beberapa siswa cenderung mengalami kesulitan dalam memahami maksud soal karena terlalu panjang; dan (2) siswa sulit untuk mengubah soal ke dalam bentuk representasi matematis berupa gambar, simbol, maupun persamaan matematika, sehingga hasil belajar siswa terutama pada representasi matematis masih rendah. Karena pentingnya meningkatkan kemampuan representasi matematis, peneliti melakukan tes kemampuan awal siswa SMP Negeri 1 Tanah Jambo Aye pada kelas VII/6 Shift A berjumlah 10 siswa. Adapun soal yang diujikan adalah:

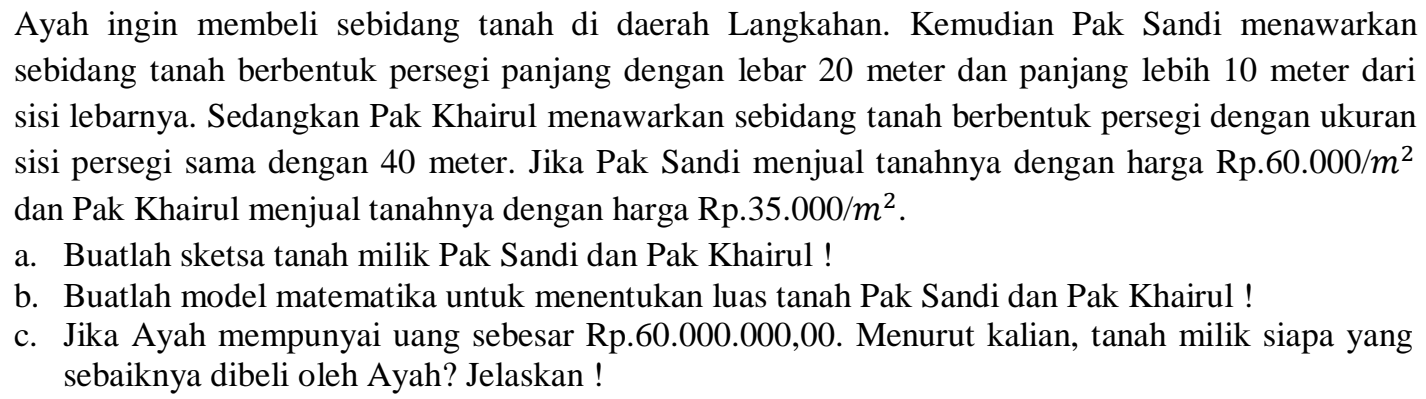

b. Buatlah model matematika untuk menentukan luas tanah Pak Sandi dan Pak Khairul !

c. Jika Ayah mempunyai uang sebesar Rp.60.000.000,00. Menurut kalian, tanah milik siapa yang sebaiknya dibeli oleh Ayah? Jelaskan!

Berikut salah satu jawaban siswa yang peneliti lakukan.

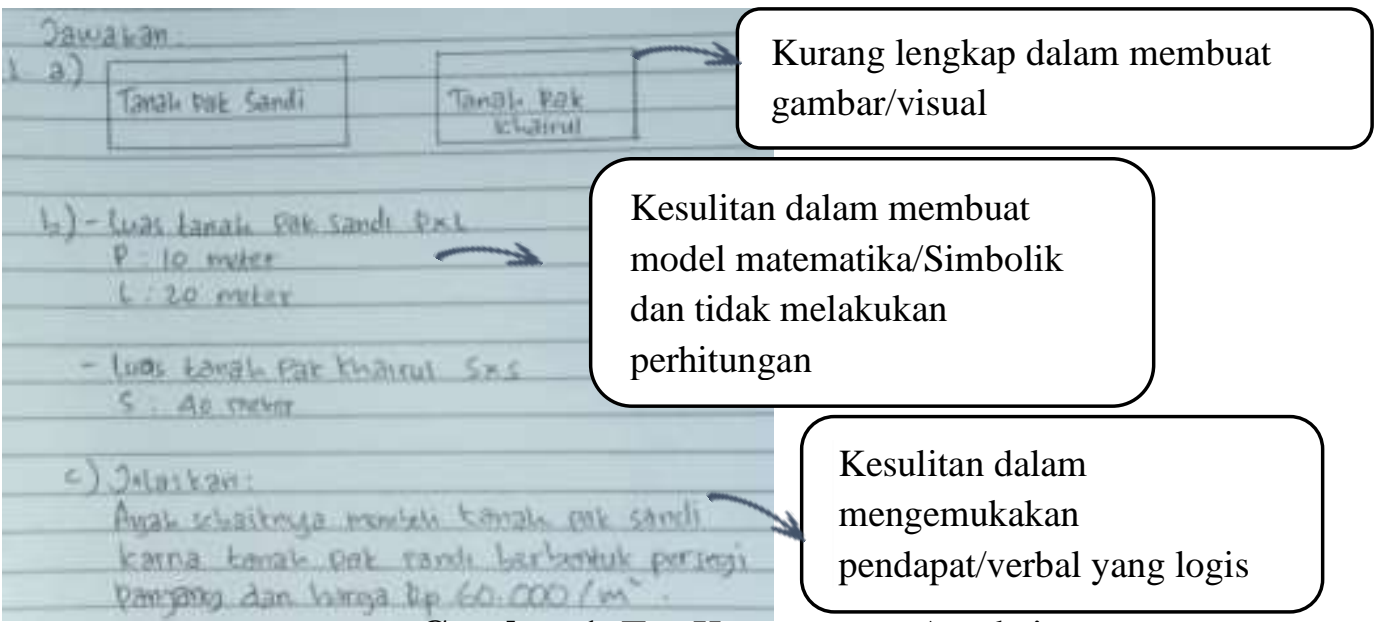

Gambar 1. Tes Kemampuan Awal siswa 


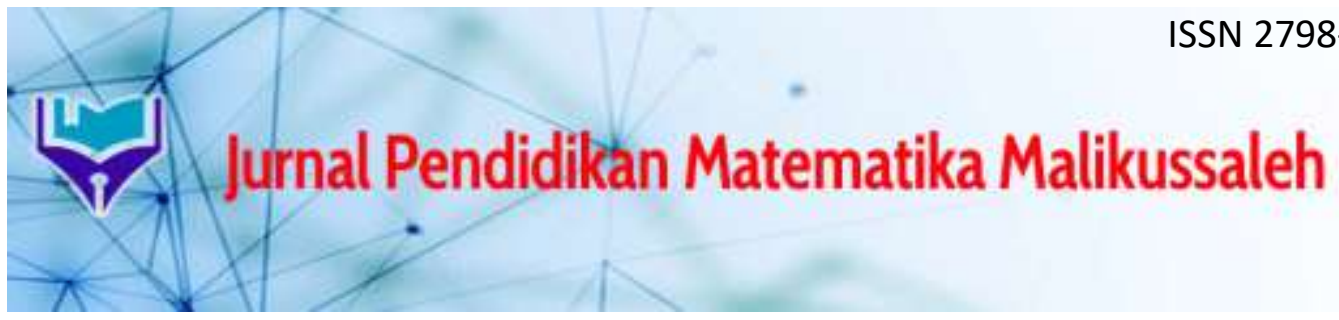

\section{Volume 1, Nomor 2, November 2021}

Dari permasalahan diatas, terdapat 3 tahap penyelesaian dalam satu permasalahan yaitu memperjelas suatu keadaan menggunakan gambar, membuat model matematika dan melakukan perhitungan, dan terakhir mengemukakan pendapat secara logis. Berdasarkan penyelesaian siswa pada tahap membuat gambar, siswa masih belum lengkap menuliskan ukuran yang sudah diketahui dalam soal, kemudian pada tahap membuat model siswa tidak melakukan perhitungan serta ada beberapa siswa yang tidak bisa membedakan antara rumus persegi panjang dan rumus persegi sehingga menyebabkan siswa keliru dalam menyelesaikan masalahnya. Dan pada tahap terakhir siswa kesulitan dalam mengemukan pendapat yang logis dan cenderung tidak bervariasi.

Berdasarkan masalah tersebut maka diperlukan strategi pembelajaran yang dapat meningkatkan kemampuan representasi matematis siswa selama proses pembelajaran berlangsung. Strategi pembelajaran yang dimaksud adalah strategi pembelajaran yang berpusat pada siswa. Selain itu, sangatlah dibutuhkan peran guru dalam memilih strategistrategi mengajar yang tepat dengan memperhatikan karakteristik-karakteristik siswa, sehingga mempunyai kesempatan bervariasi untuk mengembangkan kemampuan representasi matematis dan proses pembelajaran menjadi lebih optimal. Dengan demikian, dapat disimpulkan bahwa kemampuan representasi matematis siswa di SMP Negeri 1 Tanah Jambo Aye masih tergolong rendah.

Adapun salah satu strategi belajar yang dapat meningkatkan kemampuan representasi matematis siswa yaitu strategi Preview, Question, Read, Reflect, Recite, Review (PQ4R). Strategi ini merupakan salah satu strategi yang paling banyak dikenal untuk membantu siswa memahami dan mengingatkan materi yang mereka baca (Trianto, 2017). Strategi PQ4R ini juga membantu siswa untuk aktif dalam mengembangkan ide-ide atau informasi yang ada di dalam pikiran siswa.

Hasil penelitian sebelumnya yang dilakukan oleh (Yulianti, 2020) menunjukkan bahwa pengaruh model pembelajaran RTE dengan strategi PQ4R dapat meningkatkan kemampuan metakognitif peserta didik kelas XI di SMAN 2 Tulang Bawang Tengah. Penelitian yang dilakukan oleh (Farapatana, Anwar, Y. S, \& Abdillah, 2019) bahwa Komik matematika dengan metode $\mathrm{PQ} 4 \mathrm{R}$ pada materi segiempat telah memenuhi kriteria valid secara materi, bahasa, dan media. Sehingga penerapan metode PQ4R efektif sebagai sarana untuk mengembangkan komik matematika.

Materi yang digunakan dalam penelitian ini adalah segiempat yang diajarkan kepada siswa kelas VII semester genap. Segiempat merupakan bangun datar yang dibatasi oleh empat sisi. Materi segiempat selalu keluar saat ujian setiap tahunnya. Akan tetapi, kebanyakan siswa masih bingung dan kesulitan dalam menyelesaikan soal-soal yang ada kaitannya dengan kehidupan sehari-hari.

Berdasarkan penjelasan mengenai masalah-masalah yang telah diuraikan di atas, kiranya peneliti menemukan suatu strategi pembelajaran yang tepat untuk digunakan, yaitu strategi PQ4R (Preview, Question, Read, Reflect, Recite, and Review) yang memudahkan siswa memahami konsep apa yang mereka baca, dan diharapkan kemampuan siswa dalam menyelesaikan persoalan-persoalan matematika yang salah satunya adalah kemampuan representasi matematis juga akan meningkat. Oleh karena itu peneliti tertarik untuk mengkaji permasalahan tersebut dengan memberi judul "Penerapan Strategi Preview, Question, Read, Reflect, Recite, and Review untuk Meningkatkan Kemampuan Representasi Matematis Siswa Kelas VII SMP Negeri 1 Tanah Jambo Aye”. 


\section{Jurnal Pendidikan Matematika Malikussaleh} $x+\operatorname{lom}_{x} \times$

\section{Volume 1, Nomor 2, November 2021}

\section{METODE}

\section{Jenis Penelitian}

Penelitian ini menggunakan pendekatan kuantitatif, dimana data yang peneliti kumpulkan dalam bentuk angka-angka yang akan diuji dengan metode statistik. Pada penelitian ini, peneliti menggunakan desain penelitian eksperimen semu (Quasi Experimental) dengan rancangan Nonequivalent Control Group Design. Desain ini hampir sama dengan pretest posttest control group design, hanya pada desain ini kelompok eksperimen maupun kelompok kontrol tidak dipilih secara random. Menurut (Sugiyono, 2018), desain penelitian yang digunakan dapat digambarkan sebagai berikut:

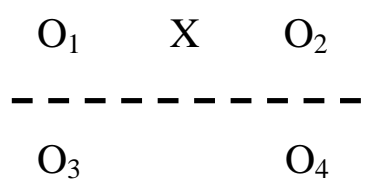

Gambar 2 Desain Penelitian

Keterangan:

$\mathrm{O}_{1}=$ Pretest untuk kelas eksperimen

$\mathrm{O}_{2}=$ Posttest untuk kelas ekperimen

$\mathrm{X}=$ Perlakuan dengan Strategi Preview, Question, Read, Reflect, Recite, Review (PQ4R)

$\mathrm{O}_{3}=$ Pretest untuk kelas kontrol

$\mathrm{O}_{4}=$ Posttest untuk kelas control

\section{Waktu dan Tempat Penelitian}

Penelitian ini dilakukan di SMP Negeri 1 Tanah Jambo Aye, Kabupaten Aceh Utara. Kegiatan penelitian ini dilaksanakan pada semester 2 (Genap) tahun ajaran 2020/2021.

\section{Populasi dan Sampel}

Populasi dalam penelitian ini adalah seluruh siswa kelas VII SMP Negeri 1 Tanah Jambo Aye. Adapun yang menjadi sampel dalam penelitian ini adalah dua kelas yaitu kelas VII/6 dan kelas VII/7. Dalam memilih sampel penelitian ini, peneliti menggunakan Purposive Sampling yaitu teknik penentuan sampel dengan cara pertimbangan.

\section{Prosedur}

Kelas eksperimen pembelajarannya menggunakan strategi Preview, Question, Read, Reflect, Recite, Review (PQ4R), sedangkan pada kelas kontrol pembelajarannya menggunakan pembelajaran saintifik. Setelah itu data harus memenuhi syarat homogenitas dan normalitas langkah terakhir dengan pengujian hipotesis.

\section{Data, Instrumen dan Teknik Pengumpulan Data}

Data dalam penelitian adalah data kuantitatif berupa skort es kemampuan representasi matematis siswa. Instrumen yang digunakan adalah tes yaitu pretest dan postest pada kelas ekksperimen dan kelas kontrol. Untuk memperoleh data kemampuan representasi matematis diperlukan pedoman penskoran sebagai acuan pemberian skor pada setiap indikator soal. Kriteria penskoran yang digunakan sebagai berikut: 


\section{Jurnal Pendidikan Matematika Malikussaleh}

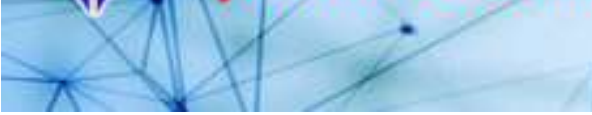

\section{Volume 1, Nomor 2, November 2021}

Tabel 1 Pedoman Penskoran Kemampuan Representasi matematis materi Segiempat

\begin{tabular}{|c|l|l|l|}
\hline Skor & \multicolumn{1}{|c|}{ Visual } & \multicolumn{1}{|c|}{ Simbolik } & \multicolumn{1}{c|}{ Verbal } \\
\hline 0 & $\begin{array}{l}\text { Tidak ada jawaban, kalaupun ada hanya memperlihatkan ketidakpahaman tentang konsep } \\
\text { sehingga informasi yang diberikan tidak berarti apa-apa. }\end{array}$ \\
\hline 1 & $\begin{array}{l}\text { Membuat gambar akan } \\
\text { tetapi tidak lengkap }\end{array}$ & $\begin{array}{l}\text { Membuat model matematika namun } \\
\text { masih terdapat kesalahan }\end{array}$ & $\begin{array}{l}\text { Menulis penjelasan } \\
\text { namun tidak logis }\end{array}$ \\
\hline 2 & $\begin{array}{l}\text { Membuat gambar secara } \\
\text { lengkap namun masih ada }\end{array}$ & $\begin{array}{l}\text { Membuat model matematika dengan } \\
\text { benar, namun terdapat sedikit } \\
\text { kesalahan pada perhitungan dan } \\
\text { penulisan simbol }\end{array}$ & $\begin{array}{l}\text { Menulis penjelasan } \\
\text { secara logis dan benar } \\
\text { namun tidak lengkap } \\
\text { atau terdapat sedikit } \\
\text { kesalahan bahasa }\end{array}$ \\
\hline 3 & $\begin{array}{l}\text { Membuat gambar secara } \\
\text { benar dan lengkap }\end{array}$ & $\begin{array}{l}\text { Membuat model matematika dengan } \\
\text { benar dan melakukan perhitungan } \\
\text { secara benar dan lengkap }\end{array}$ & $\begin{array}{l}\text { Menulis penjelasan } \\
\text { secara logis, benar dan } \\
\text { lengkap }\end{array}$ \\
\hline
\end{tabular}

Sumber : dimodifikasi dari Cai dkk (Yustika \& Roesdinan, L, 2021)

\section{HASIL DAN PEMBAHASAN}

Penelitian ini dimaksudkan untuk mengetahui peningkatan kemampuan representasi matematis siswa yang memperoleh pembelajaran saintifik dengan strategi PQ4R lebih baik dari pada dengan menggunakan pembelajaran saintifik pada kelas VII di SMP Negeri 1 Tanah Jambo Aye. Penelitian ini bersifat kuantitatif dimana data yang diperoleh berbentuk angka yang kemudian dianalisis menggunakan Software Microsoft Office Excel 2007 dan SPSS versi 17.

Berikut kesimpulan dari hasil uji validitas, realibilitas, tingkat kesukaran dan daya pembeda tes kemampuan representasi matematis siswa disajikan dalamm tabel berikut :

Tabel 2 Hasil Analisis Item Tes Kemampuan Representasi Matematis Siswa

\begin{tabular}{|c|c|c|c|c|c|}
\hline No. Soal & Validitas & Reliabilitas & Daya Pembeda & $\begin{array}{c}\text { Tingkat } \\
\text { Kesukaran }\end{array}$ & Keterangan \\
\hline 1. & Valid & \multirow{6}{*}{ Sedang } & Rendah & Mudah & Digunakan \\
\hline 2. & Valid & & Baik & Sedang & Digunakan \\
\hline 3. & Valid & & Sangat Baik & Sedang & Digunakan \\
\hline 4. & Tidak Valid & & Rendah & Sukar & Tidak Digunakan \\
\hline 5. & Tidak Valid & & Sangat Rendah & Sukar & Tidak Digunakan \\
\hline 6. & Valid & & Rendah & Sedang & Digunakan \\
\hline
\end{tabular}

Berdasarkan hasil analisis validitas, reliabilitas, daya pembeda dan tingkat kesukaran tes kemampuan representasi matematis siswa yang telah diuji coba. Soal yang akan diambil sebanyak empat soal yaitu soal nomor 1, 2, 3 dan 6 . Selanjutnya soal tersebut akan digunakan sebagai soal pretest dan posttest.

Berdasarkan hasil penelitian analisis data yang dilakukan terhadap data kuantitatif melalui tes kemampuan representasi matematis siswa. Tes diberikan kepada 42 siswa yang terdiri atas 21 siswa pada kelas eksperimen dan 21 siswa pada kelas kontrol. Tes dilakukan sebanyak dua kali yaitu sebelum dan sesudah diberi perlakuan. Berikut ini adalah tabel yang menggambarkan data deskriptif pretest, posttest, dan $N$-Gain untuk tes kemampuan representasi matematis siswa. 


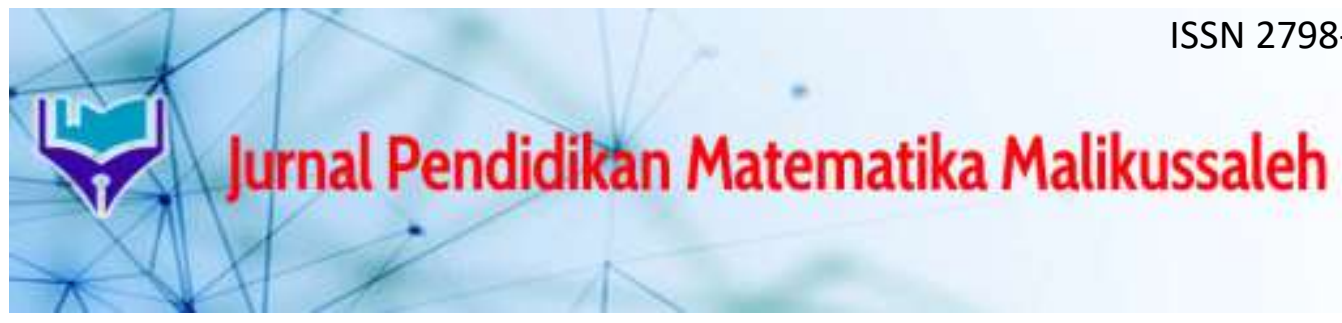

\section{Volume 1, Nomor 2, November 2021}

Tabel 3 Data Skor Kemampuan Representasi Matematis Siswa

\begin{tabular}{|c|c|c|c|c|c|c|c|}
\hline Variabel & Data & \multicolumn{3}{|c|}{ Eksperimen } & \multicolumn{3}{c|}{ Kontrol } \\
\cline { 3 - 8 } & Statistik & Pretest & Posttest & N-Gain & Pretest & Posttest & N-Gain \\
\cline { 2 - 8 } & $\mathrm{N}$ & 21 & 21 & 21 & 21 & 21 & 21 \\
\cline { 2 - 8 } $\begin{array}{c}\text { Kemampuan } \\
\text { Representasi } \\
\text { Matematis }\end{array}$ & $\mathrm{X}_{\text {maks }}$ & 7 & 21 & 1,00 & 7 & 18 & 0,80 \\
\cline { 2 - 8 } & $\mathrm{X}_{\min }$ & 1 & 10 & 0,45 & 1 & 8 & 0,35 \\
\cline { 2 - 8 } & $\bar{x}$ & 3,29 & 16,24 & 0,74 & 3,57 & 12.95 & 0,55 \\
\cline { 2 - 8 } & $\mathrm{S}$ & 1,98 & 3,09 & 0,15 & 2,11 & 2.72 & 0,11 \\
\cline { 2 - 8 } & $\%$ & 15,66 & 77,33 & 3,52 & 17,00 & 61.66 & 2,61 \\
\hline \multicolumn{6}{|c|}{ Skor Maksimal Ideal = 21 } \\
\hline
\end{tabular}

Dari tabel 3 di atas dapat dilihat hasil rataan skor pretest kelas eksperimen dan kelas kontrol masing-masing adalah 3,29 dan 3,57 dari hasil kemampuan representasi matematis kedua kelas tersebut terdapat perbedaan. Rataan skor posttest kelas eksperimen dan kelas kontrol adalah 16,24 dan 12,95. Dari hasil tersebut dapat disimpulkan bahwa terdapat peningkatan kemampuan representasi matematis siswa setelah melaksanakan pembelajaran.

Adapun sebelum melakukan uji hipotesis, terlebih dahulu dilakukan pengujian prasyarat yang meliputi uji normalitas dan uji homogenitas. Berikut ini adalah uraian mengenai hasil pengujian normalitas dan homogenitas terhadap data skor kemampuan representasi matematis siswa yang diolah dengan program SPSS versi 17. Adapun hasil perhitungan uji normalitas yang diperoleh pada penelitian ini disajikan dalam tabel berikut.

Tabel 4 Data Hasil Uji Normalitas Skor $N$-gain

Kemampuan Representasi Matematis Siswa

\begin{tabular}{|l|c|c|c|c|}
\hline \multirow{2}{*}{\multicolumn{1}{|c|}{ Kelas }} & \multicolumn{3}{c|}{ Saphiro-Wilk } & \multirow{2}{*}{ Kesimpulan } \\
\cline { 2 - 4 } & Statistik & Df & Sig. & \\
\hline Eksperimen & 0,969 & 21 & 0,714 & $\mathrm{H}_{0}$ diterima \\
\hline Kontrol & 0,974 & 21 & 0,829 & $\mathrm{H}_{0}$ diterima \\
\hline
\end{tabular}

Berdasarkan tabel di atas mengenai hasil uji normalitas skor $N$-Gain kemampuan representasi matematis siswa pada kelas eksperimen dan kelas kontrol diperoleh nilai sig. $\geq \alpha$ $=0,05$ sehingga $\mathrm{H}_{0}$ diterima. Jadi data skor $N$-Gain kemampuan representasi matematis siswa pada kelas eksperimen dan kelas kontrol berdistribusi normal. Untuk lebih jelas dapat dilihat dalam bentuk grafik berikut.

Normal Q-QPlot of NGain_Score

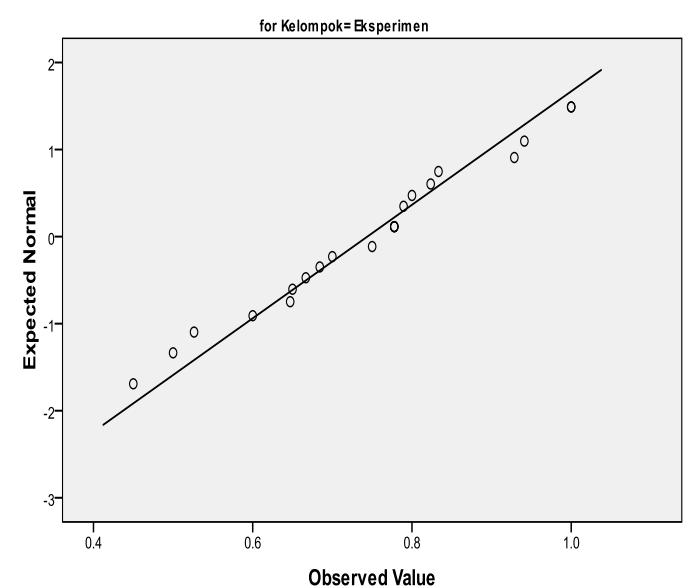

Normal Q-Q Plot of NGain_Score

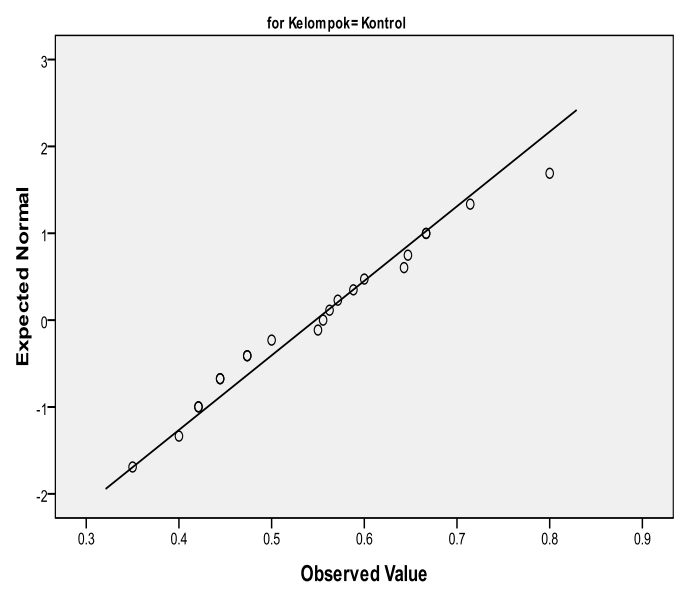

Gambar 3 Grafik Uji Normalitas Skor N-Gain Kelas Eksperimen dan Kelas Kontrol 


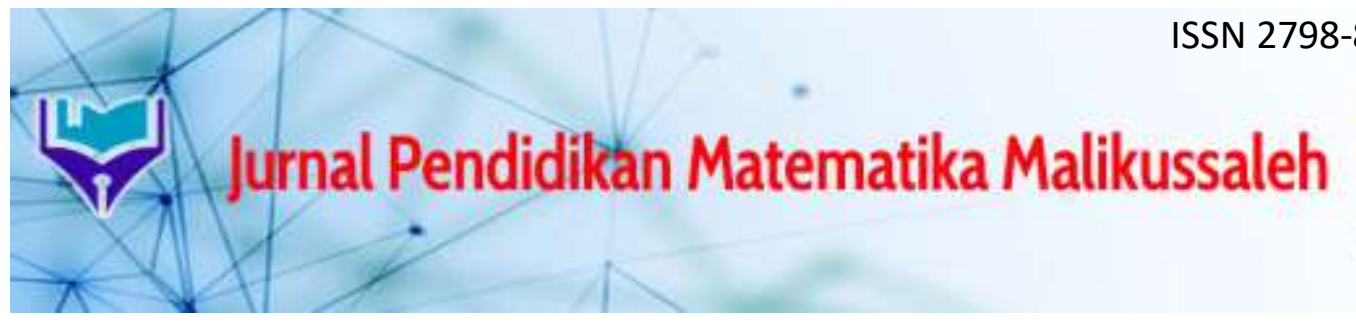

\section{Volume 1, Nomor 2, November 2021}

Berdasarkan kedua gambar grafik Normal Q-Q Plot diatas memperlihatkan bahwa titiktitik tersebut mendekati bahkan ada yang menempel pada garis diagonal, hal ini membuktikan bahwa data skor $N$-Gain berdistribusi normal.

Setelah data skor $\mathrm{N}$-Gain berdistribusi normal, kemudian dilanjutkan dengan pengujian homegenitas. Uji homogenitas dimaksudkan untuk mengetahui apakah data yang dihasilkan berasal dari varians yang homogen. Kriteria pengujiannya yaitu $\mathrm{H}_{0}$ diterima apabila nilai sig $\geq$ 0,05 , dan ditolak $\mathrm{H}_{0}$ ditolak apabila nilai sig $<0,05$. Adapun hasil perhitungan uji homogenitas yang diperoleh pada penelitian ini disajikan dalam tabel berikut.

Tabel 5 Data Hasil Uji Homogenitas Skor $N$-gain

Kemampuan Representasi Matematis Siswa

\begin{tabular}{|c|l|c|c|c|c|c|}
\hline \multicolumn{2}{|c|}{ Hasil } & Levene Statistik & $d f 1$ & $d f 2$ & Sig. & Keterangan \\
\hline \multirow{2}{*}{$\begin{array}{c}\text { N-Gain } \\
\text { Score }\end{array}$} & Eksperimen & 1,170 & 1 & 40 & 0,286 & $\mathrm{H}_{0}$ diterima \\
\cline { 2 - 4 } & Kontrol & & 1 &
\end{tabular}

Tabel di atas memperlihatkan bahwa hasil signifikan dari data yang diperoleh adalah 0,286 hal ini menunjukkan bahwa $\mathrm{H}_{0}$ diterima, karena nilai signifikannya lebih dari 0,05. Sehingga dapat disimpulkan bahwa data skor $\mathrm{N}$-Gain kemampuan representasi matematis siswa dari varians yang homogen.

Setelah mengetahui bahwa data yang diperoleh berdistribusi normal dan homogen maka dilanjutkan dengan uji-t atau pengujian hipotesis. Pengujian hipotesis ini untuk mengetahui apakah peningkatan kemampuan representasi matematis siswa yang diajarkan melalui pembelajaran saintifik dengan strategi PQ4R lebih baik dari pada kemampuan representasi matematis siswa yang diajarkan melalui pembelajaran saintifik saja. Pengujian hipotesis ini dilakukan ke uji-t menggunakan Compare Means Independent-Samples T Test. Kriteria pengujian hipotesis adalah ditolak $\mathrm{H}_{0}$ apabila sig $<0,05$ dan diterima $\mathrm{H}_{0}$ apabila sig $\geq$ 0,05 . Adapun hasil perhitungan uji-t yang diperoleh pada penelitian ini disajikan dalam tabel berikut.

Tabel 6 Data Hasil Uji T Skor $N$-gain Kemampuan Representasi Matematis Siswa

\begin{tabular}{|c|c|c|c|}
\hline \multicolumn{2}{|c|}{$t$-test for Equality of Means (Equal Variances Assumed) } & \multirow{2}{*}{ Keterangan } \\
\hline$T$ & $D f$ & Sig. (2-tailed) & \\
\hline 4,678 & 40 & 0,000 & $\mathrm{H}_{0}$ ditolak \\
\hline
\end{tabular}

Dari tabel di atas diperoleh hasil uji t Sig. (1-tailed) yaitu 0,000 yang artinya kurang dari 0,05 sehingga $\mathrm{H}_{0}$ ditolak dan $\mathrm{H}_{a}$ diterima. Dapat disimpulkan bahwa kemampuan representasi yang diajarkan menggunakan pembelajaran saintifik dengan strategi PQ4R lebih baik secara signifikan dari pada kemampuan representasi yang diajarkan menggunakan pembelajaran saintifik saja.

Pada penelitian ini, kemampuan representasi matematis siswa dilihat dari hasil pretest yang dilakukan sebelum diberikan perlakuan dan nilai posttest yang dilakukan setelah diberikan perlakuan. 


\section{Volume 1, Nomor 2, November 2021}

Berikut salah satu contoh soal dan jawaban pretest dan posttest siswa berdasarkan indikator kemampuan representasi matematis siswa yaitu Representasi Berupa Notasi (Simbolik).

\section{Soal nomor 1}

Paman Ahmad akan membuat sebuah kolam ikan di halaman belakang rumahnya. Jika panjang kolam tersebut adalah 20 meter dan ukuran lebarnya $\frac{1}{2}$ dari ukuran panjangnya, maka tentukanlah luas kolam ikan yang akan dibuat oleh Paman Ahmad?

Gambar 4 Soal Tes Kemampuan Reprentasi Matematis Siswa

* Hasil Jawaban Pretest pada Kelas Eksperimen dan Kelas Kontrol

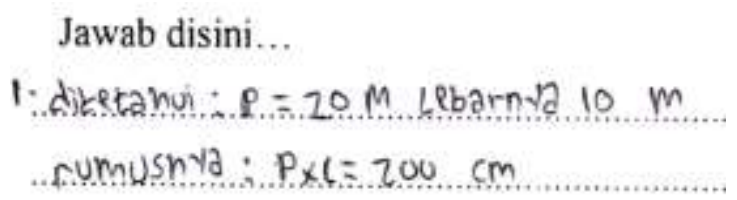

Gambar 5 Jawaban Pretest pada Kelas Eksperimen

Jawaban siswa pada gambar 5 diatas bisa dikatakan mayoritas siswa sudah paham dalam menentukan luas persegi panjang yang ditanyakan, tetapi tidak terdapat tahap-tahap penyelesaian dan kurang teliti dalam menuliskan satuan akhir pada soal, sehingga jawaban kurang tepat.

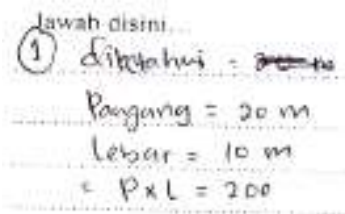

\section{Gambar 6 Jawaban Pretest pada Kelas Kontrol}

Paparan diatas, memberikan gambaran bahwa siswa sudah menyelesaikan soal dengan benar, hanya saja perhitungan yang digunakan cenderung menuliskan jawaban akhir saja serta tidak membuat satuan dari ukuran luas, seharusnya dari jawaban tersebut dituliskan $200 \mathrm{~m}^{2}$, sehingga jawaban tersebut dikategorikan kurang lengkap.

* Hasil Jawaban Posttest pada Kelas Eksperimen dan Kelas Kontrol

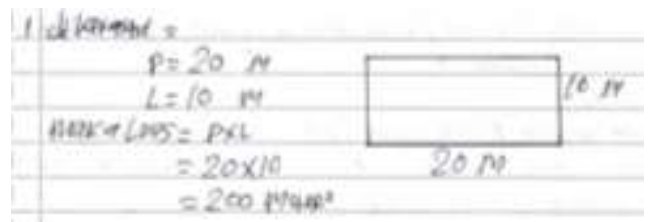

Gambar 7 Jawaban Posttest pada Kelas Eksperimen

Gambar 7 diatas memberikan informasi bahwa siswa sudah mampu memahami soal, menuliskan rumus yang tepat dan menggambarkan ilustrasi berupa gambar serta penyelesaiannya sudah tersusun rapi sehingga jawaban benar dan lengkap. 


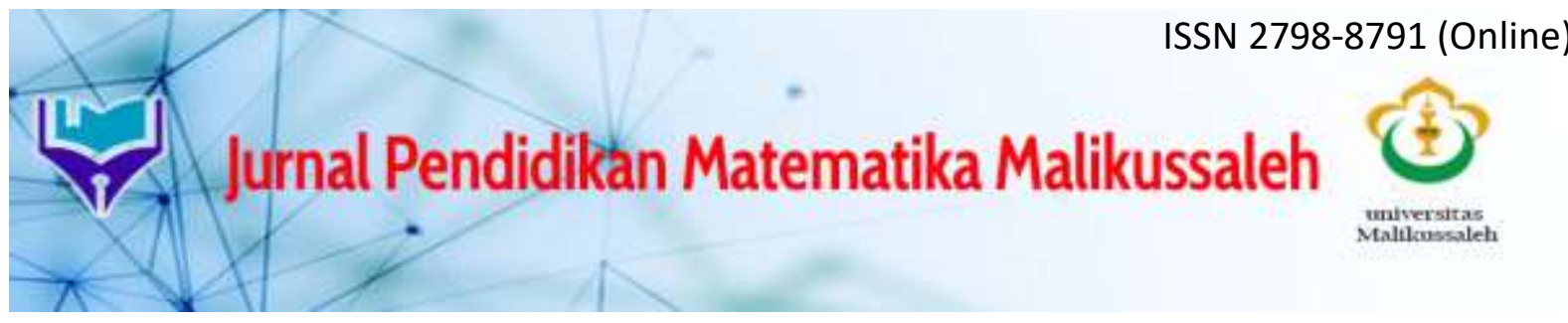

Volume 1, Nomor 2, November 2021

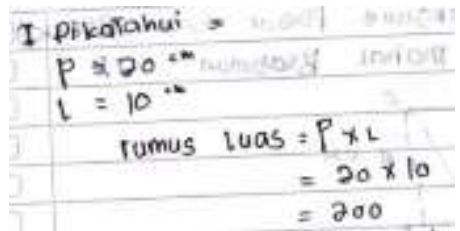

Gambar 8 Jawaban Posttest pada Kelas Kontrol

Bertolak dari gambar 7 diatas gambar ini memberikan informasi yaitu siswa sudah mengetahui rumus dan sudah menyelesaikan soal dengan benar hanya saja tidak menggambarkan ilustrasi berupa gambar dan tidak menuliskan satuan akhir dari soal sehingga jawaban masih kurang lengkap.

Berdasarkan jawaban pretest dan posttest siswa pada kelas eksperimen dan kelas kontrol dari soal diatas yang telah dideskripsikan yaitu siswa diminta membuat model matematika untuk menentukan nilai luas dari persegi panjang berdasarkan informasi yang telah diketahui dari sisi bangun datar tersebut. Pada gambar pretest kedua kelas tersebut sekilas terlihat bahwa hasil jawaban siswa kelas kontrol dan kelas eksperimen memiliki kemiripan namun terdapat perbedaan dalam langkah pengerjaan dan hasilnya belum maksimal. Dari hasil jawaban posttest siswa terlihat bahwa sebagian kecil kelompok kontrol dan sebagian besar kelompok eksperimen sudah mampu membuat model matematika dengan benar dan juga melakukan perhitungan dengan benar. Perbedaannya terletak pada penulisan simbol untuk satuan akhir dari luas persegi panjang tersebut yaitu $\mathrm{m}^{2}$. Siswa pada kelas kontrol tidak menuliskan simbol akhir dalam penyelesaian masalah dan beberapa siswa belum mampu memberikan penjelasan yang tepat mengenai soal tersebut.

Berdasarkan pemaparan di atas, maka terbukti bahwa strategi pembelajaran PQ4R mempengaruhi kemampuan representasi matematis siswa dibandingkan dengan pembelajaran saintifik saja. Hasil penelitian ini dapat di lihat dari jawaban pretest dan posttest siswa pada kelas eksperimen dan kelas kontrol. Jawaban pretest siswa pada kelas eksperimen dan kelas kontrol masih tidak jauh berbeda dalam penyelesaiannya, dimana masih sama-sama belum bisa menyelesaikan langkah-langkah penyelesaian soal secara terperinci. Sedangkan Jawaban posttest siswa pada kelas eksperimen dan kelas kontrol juga tidak jauh berbeda dalam penyelesaiannya, akan tetapi jawaban posttest siswa pada kelas eksperimen memiliki ketuntasan belajar yang lebih tinggi dari pada kelas kontrol.

\section{KESIMPULAN}

Berdasarkan hasil penelitian yang telah dilaksanakan dapat disimpulkan bahwa peningkatan kemampuan representasi matematis siswa yang memperoleh pembelajaran saintifik dengan strategi PQ4R lebih baik daripada kemampuan representasi matematis siswa yang menggunakan pembelajaran saintifik pada kelas VII di SMP Negeri 1 Tanah Jambo Aye. 


\section{Jurnal Pendidikan Matematika Malikussaleh}

$x+10$

universitas
Malllowssaleh

Volume 1, Nomor 2, November 2021

\section{DAFTAR PUSTAKA}

Arikunto. (2019). Prosedur Penelitian Suatu Pendekatan Praktik. Jakarta: PT Rineka Cipta.

Farapatana, E., Anwar, Y. S, \& Abdillah. (2019). Pengembangan Komik Matematika dengan Metode Preview, Question, Read, Reflect, Recite \& Review (PQ4R) Pada Materi Lingkaran Kelas VIII SMP. Jurnal Teori dan Aplikasi Matematika (JTAM), 3 (1) : 16.

Mariyam, Nurdin, \& Utami, C. (2019). Penerapan Model Pembelajaran Kooperatif Tipe Team Assisted Individualization (TAI) Untuk Meningkatkan Kemampuan Komunikasi Matematis Siswa Pada Materi Sistem Persamaan Linear Dua Variabel Kelas VIII. Journal of Educational Review and Research, 1-11.

NCTM. (2000). Principles and Standars for School Mathematics. Virginia: NCTM.

Sugiyono. (2018). Metode Penelitian Kuantitatif, Kualitatif dan R \& D. Bandung: Alfabeta.

Trianto. (2017). Mendesain Model Pembelajaran Inovatif, Progresif dan Kontekstual. Jakarta: Prenada Media.

Yulianti, A. (2020). Pengaruh Model Pembelajaran Rotating Trio Exchange (RTE) dengan Strategi PQ4R Terhadap Kemampuan Metakognitif Peserta Didik. Lampung: (Skripsi) Universitas Islam Negeri Raden Intan.

Yustika, A., \& Roesdinan, L. (2021). Analisis Kemampuan Representasi Matematis Siswa SMP Pada Materi Segiempat dan Segitiga. Journal Unsika. 